\title{
Differential Behaviours and Preferential Bindings of Influenza Nucleoproteins on Importins- $\alpha$
}

\author{
Amélie Donchet, Emilie Vassal-Stermann $₫$, Francine C. A. Gérard ${ }^{\circledR}$, Rob W. H. Ruigrok $₫$ and \\ Thibaut Crépin *(1) \\ Centre National de la Recherche Scientifique (CNRS), Institut de Biologie Structurale (IBS), \\ University Grenoble Alpes, Commissariat à l'Energie Atomique et aux Energies Alternatives (CEA), \\ 38044 Grenoble, France; amelie.donchet@ibs.fr (A.D.); emilie.stermann@ibs.fr (E.V.-S.); \\ francine.baraggia@grenoble-inp.fr (F.C.A.G.); rob.ruigrok@ibs.fr (R.W.H.R.) \\ * Correspondence: thibaut.crepin@ibs.fr; Tel.: +33-(0)476-209-439 \\ + Current address: Laboratoire des Matériaux et du Génie Physique (LMGP), University Grenoble Alpes, \\ CNRS, Institut Polytechnique de Grenoble (Grenoble INP), F-38000, Grenoble, France.
}

Received: 30 May 2020; Accepted: 27 July 2020; Published: 30 July 2020

check for updates

\begin{abstract}
Influenza viruses are negative single-stranded RNA viruses with nuclear transcription and replication. They enter the nucleus by using the cellular importin- $\alpha /-\beta$ nuclear import machinery. Influenza nucleoproteins from influenza $\mathrm{A}, \mathrm{B}, \mathrm{C}$ and $\mathrm{D}$ viruses possess a nuclear localization signal (NLS) localized on an intrinsically disordered extremity ( $\mathrm{NP}_{\mathrm{TAIL}}$ ). In this paper, using size exclusion chromatography (SEC), SEC-multi-angle laser light scattering (SEC-MALLS) analysis, surface plasmon resonance (SPR) and fluorescence anisotropy, we provide the first comparative study designed to dissect the interaction between the four $\mathrm{NP}_{\text {TAILs }}$ and four importins- $\alpha$ identified as partners. All interactions between $\mathrm{NP}_{\text {TAILs }}$ and importins- $\alpha$ have high association and dissociation rates and present a distinct and specific behaviour. $\mathrm{D} / \mathrm{NP}_{\mathrm{TAIL}}$ interacts strongly with all importins- $\alpha$ while $\mathrm{B} / \mathrm{NP}_{\text {TAIL }}$ shows weak affinity for importins- $\alpha$. $\mathrm{A} / \mathrm{NP}_{\text {TAIL }}$ and $\mathrm{C} / \mathrm{NP}_{\text {TAIL }}$ present preferential importin- $\alpha$ partners. Mutations in $\mathrm{B} / \mathrm{NP}_{\mathrm{TAIL}}$ and $\mathrm{D} / \mathrm{NP}_{\mathrm{TAIL}}$ show a loss of importin- $\alpha$ binding, confirming key NLS residues. Taken together, our results provide essential highlights of this complex translocation mechanism.
\end{abstract}

Keywords: influenza nucleoprotein; nuclear transport; importin- $\alpha$; nuclear localization signal; influenza-host interaction; surface plasmon resonance; fluorescence anisotropy

\section{Introduction}

Influenza viruses are part of the Orthomyxoviridae family and form the genus Influenzavirus. Up to now, the International Committee officially recognizes four types (respectively types A, B, C and D) in its Taxonomy of Viruses (ICTV), but because of actual large-scale meta-transcriptomic approaches new specimens are regularly discovered, making this classification a constantly evolving entity. While influenza viruses were thought to be uniquely warm-blooded organism pathogens, a study has recently uncovered their existence in fish and amphibians in China [1]. A first criterion of distinction between the actual four types of Influenzavirus is based on their tropism. Influenza type A viruses (IAV) are viruses from water fowl but some of the viruses can also infect a range of hosts from chickens to swine and humans; type B (IBV) almost exclusively infect humans; type C (ICV) can infect both human and swine whereas type D (IDV) has a broad host tropism but limited to mammals. Influenza viruses are negative-sense single-stranded RNA viruses with segmented genomes. The RNA segments are packaged in ribonucleoproteins (RNPs), a complex architecture made by a single RNA molecule encapsidated by multiple copies of the nucleoprotein (NP) and the heterotrimeric RNA-dependent 
RNA polymerase (RdRp) bound to the strictly conserved $3^{\prime}$ and $5^{\prime}$ end [2,3]. The number of RNPs varies depending on the type: IAV and IBV genomes consist of eight RNA segments, i.e., there are eight different RNPs, but only seven for ICV and IDV viruses. This is related to the inherent organisation of the viral spikes, respectively the haemagglutinin (HA) plus the neuraminidase (NA) for A and B or a single hemagglutinin-esterase-fusion (HEF) polypeptide with both concatenated activities for $\mathrm{C}$ and $\mathrm{D}$.

Unlike most RNA viruses, influenza viruses transcribe and replicate their genome in the nucleus of infected cells. In general, the access to the nuclear compartment is through the highly regulated nuclear pore complex (NPC) [4-7]. Several pathways are involved in cytoplasmic-nuclear trafficking. Small molecules $(<30-60 \mathrm{kDa})$ are able to diffuse passively through the NPC but bigger molecules often require an active mechanism to be imported [8-10]. The main active transport is based on the importins- $\alpha / \beta$ (coupled to the small GTPase Ran) pathway. Importins- $\alpha$ and $-\beta$ can both interact with the cargos but only the last ones mediate directly the translocation, and importin- $\alpha$ :cargo complexes must first interact with importin- $\beta[11,12]$. Cargos are recognized by importins- $\alpha / \beta$ through nuclear localization signals (NLSs), usually made of basic or hydrophobic motifs $[13,14]$. Additionally to the interaction with the NLS motifs, recent karyopherins- $\beta /$ cargo-protein structures have demonstrated that these complexes are dependent on multiple interactions, mediated through intricate 3D interfaces which involve residues well beyond the NLS peptide stretch [15-17].

The human genome encodes for seven importins- $\alpha$ and at least twenty importins- $\beta[9,18,19]$, meaning that the importins $\alpha / \beta$ pathway is a difficult problem. Nuclear import of influenza virus proteins has been of a major interest for a long time [20,21]. Considering the neo-synthetized components of the replication machinery, two subunits (PA and PB1) of the heterotrimeric RdRp are imported as a sub-complex by the importin- $\beta$ RanBP5 $[17,22-24]$ whereas the third subunit (PB2) and NP interact with importins- $\alpha$ [25-28]. Because of its role in the RNPs formation, NP is critical for influenza replication but also shown to be the major contributor to the nuclear transport of the RNPs [29]. The NLS of NPs are located in intrinsically disordered tails of the proteins, either in $\mathrm{N}_{\text {terminal }}$ for $\mathrm{A} /$ and $\mathrm{B} / \mathrm{NP}$ or in $\mathrm{C}_{\text {terminal }}$ for $\mathrm{C} /$ and $\mathrm{D} / \mathrm{NP}$ (Figure 1). A minor putative NLS has been located in a loop of the core of $\mathrm{A} / \mathrm{NP}$, between residues 198 to 216, but its role remains unclear [30,31]. A/NP is known to interact with several importin- $\alpha$ isoforms, including the universal $-\alpha 1,-\alpha 3,-\alpha 5$ and possibly $-\alpha 7$ [32-36]. In recent years, our group has worked on the mechanisms of the interaction between two different NPs and the human nuclear trafficking machinery $[37,38]$, in particular the tails containing the NLS of influenza $\mathrm{B}\left(\mathrm{B} / \mathrm{NP}_{\mathrm{TAIL}}\right)$ and $\mathrm{D}\left(\mathrm{D} / \mathrm{NP}_{\mathrm{TAIL}}\right) \mathrm{NPs}$. We showed that the $\mathrm{NLS}$ of $\mathrm{B} / \mathrm{NP}_{\mathrm{TAIL}}$ is highly extended from residues 30 to 71, around a single basic Lysine-Arginine (44-KR-45) patch, with a low affinity of $844 \mathrm{nM}$ for the human importin- $\alpha 7$. In the case of the $\mathrm{C}_{\text {terminal }} \mathrm{D} / \mathrm{NP}_{\mathrm{TAIL}}$, the NLS was composed of two basic KR patches, respectively 514-KR-515 and 532-KR-533. Both contribute to the nuclear trafficking and we estimated that the affinity of $\mathrm{D} / \mathrm{NP}_{\mathrm{TAIL}}$ for the human importin- $\alpha 7$ was at $100 \mathrm{nM}$ by surface plasmon resonance (SPR). The literature also contains several studies detailing the relation between A/NP and C/NP and importins- $\alpha$ [21,29,31,33,39-43] (Table 1). However, recent work highlighted that each importin- $\alpha$ is unique, with its own features and preferential partners $[28,35,44,45]$.

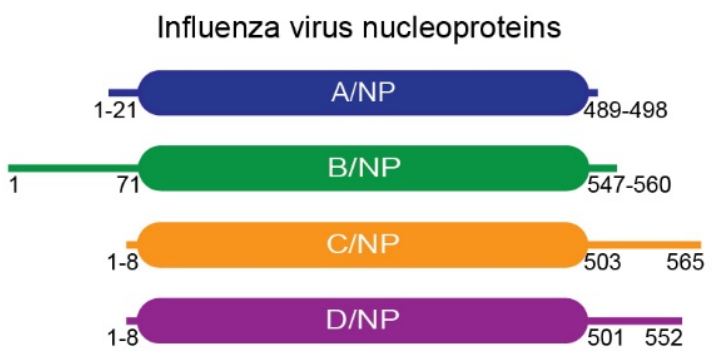

Figure 1. Influenzavirus nucleoproteins. The schematic representations of Influenzavirus nucleoproteins are based on this structural analysis [37]. The schema respects the size of the proteins. The flexible tails with the NLSs are represented with simple lines whereas the cores are represented with filled boxes. 
Table 1. Binding of influenza nucleoproteins or their peptides to importins- $\alpha$ according to the literature. Abbreviations: ITC, isothermal titration calorimetry; SPBA, solid phase binding assay; MT, microscale thermophoresis; SPR, surface plasmon resonance.

\begin{tabular}{cccccc}
\hline & Construct & Importin- $\alpha$ & Method & $\mathbf{K}_{\mathbf{d}}$ & Ref \\
\hline A/NP & R416A & $\alpha 5$ & ITC & $26 \mathrm{nM}$ & {$[41]$} \\
A/NP & $2-15$ & $\alpha 1$ & SPBA & $1.7 \mu \mathrm{M}$ & {$[42]$} \\
A/NP & $1-13$ & $\alpha 1$ & ITC & $5 \mu \mathrm{M}$ & {$[31]$} \\
A/NP & $198-216$ & $\alpha 1$ & ITC & $72 \mu \mathrm{M}$ & {$[31]$} \\
B/NP & $1-70$ & $\alpha 7$ & ITC & $844 \mathrm{nM}$ & {$[38]$} \\
C/NP & $506-565$ & $\alpha 1$ & MT & $48 \mathrm{nM}$ & {$[43]$} \\
D/NP & $505-552$ & $\alpha 7$ & SPR & $100 \mathrm{nM}$ & {$[37]$} \\
\hline
\end{tabular}

Because we were confronted with a wide range of values (from $26 \mathrm{nM}$ to $72 \mu \mathrm{M}$ ) obtained using different techniques and a plethora of different partner constructs, we wanted to establish a systematic comparative study of the in vitro interaction between the flexible extremities ( $\mathrm{NP}_{\text {TAILs }}$ ) of all types of influenza NPs and the different human importin- $\alpha$ isoforms described in the literature. Our strategy was design, with a specific focus upon the short NLS sequences, and built with the objective of avoiding the inherent oligomerization of NPs, while guaranteeing the architecture of the tails in a unique globular environment. Using size exclusion chromatography experiments, we show that all $\mathrm{NP}_{\text {TAILs }}$ interact with importins- $\alpha$ in solution and then used surface plasmon resonance measurements to determine the affinity and binding kinetics of these interactions. In the current paper, we show that $\mathrm{D} / \mathrm{NP}_{\text {TAIL }}$ interacts with all importins- $\alpha$ isoforms with strong affinity. Both $\mathrm{A} / \mathrm{NP}_{\mathrm{TAIL}}$ and $\mathrm{C} / \mathrm{NP}_{\mathrm{TAIL}}$ interact with varying affinities with the corresponding importins- $\alpha$. On the other hand, $\mathrm{B} / \mathrm{NP}_{\mathrm{TAIL}}$ shows a completely different behaviour, with even faster association and dissociation rates and a low affinity with all the human importins- $\alpha$ we measured.

\section{Materials and Methods}

\subsection{Molecular Biology and Constructs}

Human importin- $\alpha 1$ (residues 69 to 529), $-\alpha 3$ (residues 64 to 521) and - $\alpha 5$ (residues 66 to 538) DNA coding sequences were bought at GENEART GmbH (Thermo Fischer Scientific, Regensburg, Germany) and subcloned into pETM11 bacterial expression vector (EMBL) without their importin- $\beta$ (IBB) domains. Human importin- $\alpha 7$ (residues 58 to 536) cloning was described in [26]. NLS-bearing $\mathrm{NP}_{\text {TAILs }}$ from strains A/WSN/1933 (residues 1 to 21), B/Memphis/13/03 (residues 1 to 71), C/Ann-Arbor/1/50 (residues 508 to 565) and D/bovine/France/2986/2012 (residues 505 to 552) were ordered from GeneART, fused to a biotinylation sequence in $\mathrm{C}_{\text {terminal }}$ (Figure 2, and details of the sequences are provided in Table S1). The $\mathrm{NP}_{\text {TAILs }}$ were fused to the yellow fluorescent protein (YFP) either in $\mathrm{C}_{\text {terminal }}\left(\mathrm{C} / \mathrm{NP}_{\text {TAIL }}\right.$ and $\left.\mathrm{D} / \mathrm{NP}_{\mathrm{TAIL}}\right)$ or in $\mathrm{N}_{\text {terminal }}\left(\mathrm{A} / \mathrm{NP}_{\mathrm{TAIL}}, \mathrm{B} / \mathrm{NP}_{\mathrm{TAIL}}\right)$ according to their native localization; at the other YFP extremity, the biotinylation sequence was added (Figure 2). $\mathrm{NP}_{\mathrm{TAILs}} \mathrm{YFP}$ constructs were subcloned into pETM11 bacterial expression vector. All constructs were expressed as N-terminally His-tagged proteins. Sequencing was performed by Eurofins Genomics (Köln, Germany). The control peptide was a synthetic peptide (GENPEP, St-Jean-de-Védas, France) corresponding to a GLA domain-derived polypeptide of the human coagulation factor $\mathrm{X}$ [46]. 
(a)

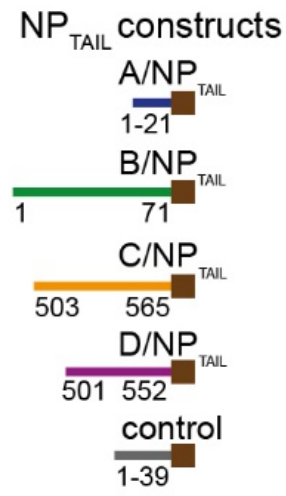

(b)

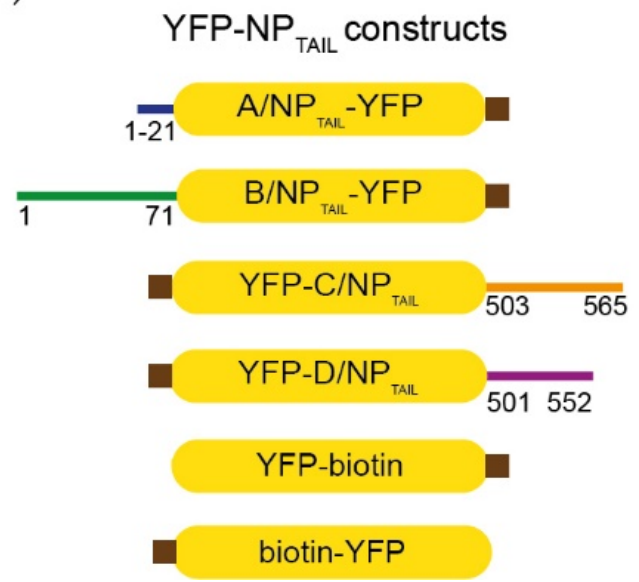

Figure 2. Constructs. (a) Influenzavirus nucleoproteins tails were expressed and purified independently fused with a biotinylation sequence (brown squares) in their $\mathrm{C}_{\text {terminal }}$ end. The details of the sequences are provided in Table S1. (b) The corresponding tails were fused to the yellow fluorescent protein (YFP) in order to integrate then in the context of a globular protein. The yellow filled boxes represent the YFP and the brown squares indicate the position of the biotinylation sequence.

\subsection{Expression and Purification}

Escherichia coli BL21 RIL (DE3) cells (Life Technologies, Thermo Fischer Scientific, Courtaboeuf, France) were used for protein expression. Cultures were supplemented with biotin $\left(12.5 \mu \mathrm{g} \cdot \mathrm{mL}^{-1}\right.$, Sigma, Saint-Quentin-Fallavier, France) to biotinylate the proteins in cellulo, induced for $12 \mathrm{~h}$ by adding $0.3 \mathrm{mM}$ isopropyl- $\beta$-D-thiogalactopyranoside (IPTG; Euromedex, Souffelweyersheim, France) at $18{ }^{\circ} \mathrm{C}$ and collected by centrifugation. Pellets were resuspended in $50 \mathrm{mM}$ Tris- $\mathrm{HCl} \mathrm{pH}$ 7.5, $300 \mathrm{mM} \mathrm{NaCl}, 2 \mathrm{mM} \beta$-mercaptoethanol ( $\beta$-ME; Roth, Lagny-sur-Marne, France) and cOmplete ${ }^{\mathrm{TM}}$, ethylenediaminetetraacetic acid (EDTA)-free protease inhibitor cocktail (Roche, Meylan, France) before sonication. All purifications included a nickel affinity chromatography (resin Ni-NTA; Qiagen, Les Ulis, France), a Tobacco Etch Virus (TEV) protease cleavage, a second nickel affinity chromatography and a size-exclusion chromatography (SEC). SEC was performed on a NGC system (Bio-Rad, Marnes-La-Coquette, France) with a S75 10/300 GL column (GE-Healthcare, Dutscher, Brumath, France). The final buffer composition for all proteins was $10 \mathrm{mM}$ Hepes $\mathrm{pH}$ 7.5, $150 \mathrm{mM} \mathrm{NaCl}$. NP $\mathrm{NAILs}_{\text {TFP }}$ protein concentrations were determined by measuring the absorbance at $280 \mathrm{~nm}$ and using the theoretical

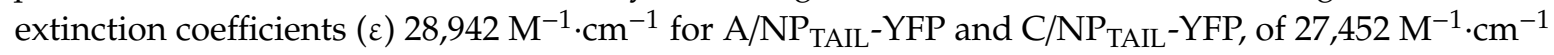
for $\mathrm{B} / \mathrm{NP}_{\mathrm{TAIL}}-\mathrm{YFP}, \mathrm{D} / \mathrm{NP}_{\mathrm{TAIL}}-\mathrm{YFP}$ and YFP control. $\varepsilon$ at $280 \mathrm{~nm}$ used for $\Delta \mathrm{IBB}$ importins- $\alpha$ protein concentrations were $50,607 \mathrm{M}^{-1} \cdot \mathrm{cm}^{-1}$ for importin- $\alpha 1,42,190 \mathrm{M}^{-1} \cdot \mathrm{cm}^{-1}$ for importin- $\alpha 3$, $52,285 \mathrm{M}^{-1} \cdot \mathrm{cm}^{-1}$ for importin- $\alpha 5$ and $46,785 \mathrm{M}^{-1} \cdot \mathrm{cm}^{-1}$ for importin- $\alpha 7$. The concentrations were then obtained using the Beer-Lambert law.

\subsection{Interaction Assays by Size Exclusion Chromatography}

All size exclusion chromatography (SEC) experiments were performed in the same buffer $(10 \mathrm{mM}$ Hepes pH 7.4, $150 \mathrm{mM} \mathrm{NaCl}$ ) using a Superdex ${ }^{\mathrm{TM}} 200$ increase 10/300GL column (GE-Healthcare) for YFP-NP TAIL $_{\text {fusion proteins and a Superdex }}{ }^{\mathrm{TM}} 75$ 10/300GL column (GE-Healthcare) for all the other $\mathrm{NP}_{\text {TAILs. }}$. Samples were diluted to be used at $30 \mu \mathrm{M}$ for YFP-NP $\mathrm{NAIL}_{\text {TAl }}$ fusion proteins, $60 \mu \mathrm{M}$ for $\mathrm{NP}_{\text {TAILs }}$ and $25 \mu \mathrm{M}$ importin- $\alpha 7$ in $300 \mu \mathrm{L}$. They were incubated for one hour at room temperature before injection on a NGC system (Bio-Rad). 


\subsection{SEC-MALLS-RI Analysis}

Size exclusion chromatography (SEC) followed by multi-angle laser light scattering (MALLS) and refractometry (RI) analysis allow the determination of the molecular mass of a protein or a complex in solution that is independent of its dimensions and shape [47]. SEC was performed with a column (Superdex ${ }^{\mathrm{TM}} 200$ increase 10/300 GL or Superdex 75 10/300 GL) equilibrated with $10 \mathrm{mM}$ Hepes $\mathrm{pH} 7.5,150 \mathrm{mM} \mathrm{NaCl}$. Analytical runs were performed at $20{ }^{\circ} \mathrm{C}$ with a flow rate of $0.5 \mathrm{~mL} \cdot \mathrm{min}^{-1}$. Multi-angle laser light scattering (MALLS) detection was performed with a DAWN-HELEOS II detector (Wyatt Technology, Toulouse, France) using a laser emitting at $690 \mathrm{~nm}$ and protein concentration was measured on-line with the use of differential refractive-index measurements, with an Optilab T-rEX detector (Wyatt Technology) and a refractive-index increment, dn/dc of $0.185 \mathrm{~mL} \cdot \mathrm{g}^{-1}$. Data were analyzed and weight-averaged molar masses were calculated using the ASTRA software (Wyatt Technology Corp., Santa Barbara, CA, USA).

\subsection{Surface Plasmon Resonance}

Surface plasmon resonance (SPR) experiments were carried out at $25^{\circ} \mathrm{C}$ on a Biacore T200 (GE Healthcare Life Sciences Europe GmbH, Velizy-Villacoublay, France). Avidin (50 $\mu \mathrm{g} \cdot \mathrm{mL}^{-1}$ in $50 \mathrm{mM}$ acetate buffer $\mathrm{pH} 4.5$; Sigma) was first immobilized on a Serie S CM5 sensor chip (GE-Healthcare) surface through amine coupling chemistry according to the manufacturer instructions, until a coupling level of about 17,000 resonance units (RUs) was reached. The biotinylated $\mathrm{NP}_{\mathrm{TAIL}}-\mathrm{YFP}\left(1-10 \mu \mathrm{g} \cdot \mathrm{mL}^{-1}\right)$ or biotinylated YFP control $\left(1-10 \mu \mathrm{g} \cdot \mathrm{mL}^{-1}\right)$ were then captured in surfactant-supplemented HBS-N running buffer (10 $\mathrm{mM}$ Hepes $\mathrm{pH} 7.4,150 \mathrm{mM} \mathrm{NaCl}, 0.05 \%$ Tween 20; GE Healthcare) at a flow rate of $30 \mu \mathrm{L} \cdot \mathrm{min}^{-1}$ until a coupling level of 100-200 RU was obtained. A flow-cell with immobilized avidin only was used as negative control while the flow-cell with the avidin: biotinylated $\mathrm{NP}_{\mathrm{TAIL}}-\mathrm{YFP}$ complex was used as active flow-cell. For kinetic measurements, importins- $\alpha$ were serial-diluted in surfactant-supplemented HBS-N running buffer. Each concentration was injected in triplicate on both the reference and active flow-cells. Analyte injection and following buffer injection times were set between 55-180 s and 55-200 s respectively, depending on the examined partners, at a flow-rate of $30 \mu \mathrm{L} \cdot \mathrm{min}^{-1}$. Regeneration was required and achieved by pulse injection of $5 \mathrm{M} \mathrm{NaCl}$. All sensorgrams were reference-subtracted. Data were analyzed with Steady State Analysis using the Biacore T200 Evaluation software (GE Healthcare) under a Langmuir 1:1 binding model, assuming that the binding is equivalent and independent for all binding site. $\mathrm{Chi}^{2}$ values for the fitting were kept below 1 for most of the analysis with a maximum of 2.5, and T-value means for the dissociation constant above 10.

\subsection{Fluorescence Anisotropy}

Fluorescence anisotropy experiments were performed on a Clariostar microplate reader (BMG Labtech, Champigny-sur-Marne, France) set and dedicated to fluorescence anisotropy measurements, with excitation and emission wavelengths fixed at 482 and $530 \mathrm{~nm}$, respectively. Importin- $\alpha 1$ was serially diluted in buffer (10 $\mathrm{mM}$ Hepes $\mathrm{pH} 7.4,150 \mathrm{mM} \mathrm{NaCl})$ and mixed in dilution series with the YFP-fused $\mathrm{NP}_{\text {TAILS }}$. YFP construct final concentration was set at $25 \mathrm{nM}$. Measurements were done in 384-well plates at room temperature. Blank substraction was done using the condition with YFP-fused $\mathrm{NP}_{\text {TAILS }}$ alone. Data were normalized using the equation:

$$
B=\frac{(\text { Aexp }-A \min )}{(\text { Amax }-A \min )}
$$

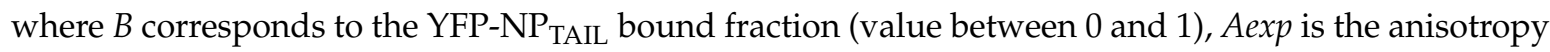
value observed for one given importin- $\alpha 1$ concentration, and Amin and Amax stand for the fluorescence anisotropy values of the free YFP-NP TAIL $_{\text {and bound YFP-NP }}$ TAIL, respectively. Titrations were then fitted to the GraphPad Prism model "Single binding site with Hill slope (h)". 


\section{Results}

\subsection{Biochemical and Biophysical Analysis of the Interaction between $N P_{\text {TAILS }}$ and Importin- $\alpha 7$}

In all experiments with NP and its partners, measurements are difficult because all NPs tend to form oligomers depending on the buffer concentrations $[41,48]$, and therefore, we used only the disordered $\mathrm{NP}_{\text {TAILs. }}$. We designed our study with a specific focus upon these short sequences that do not

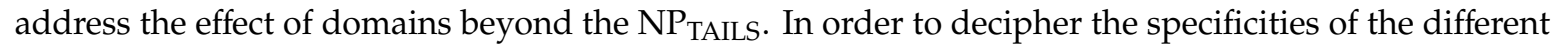
$\mathrm{NP}_{\text {TAILs }}$ for importins- $\alpha$, we first use the corresponding peptides, in size exclusion chromatography (SEC) experiments combined with surface plasmon resonance (SPR) measurements to determine the affinity and binding kinetics. The first method was used to confirm the ability of the tails to interact with its partner in solution, whereas the second method was used for the determination of the kinetic parameters of the interactions. In SPR, one partner (called the ligand) is immobilized onto a biosensor surface. The interacting partner (called the analyte) diluted in a buffer is then continuously flowed across the biosensor surface, where it binds to the ligand. The binding is measured as a change in resonance units (RUs) on the biosensor surface. Measuring the increase in binding over time for a given analyte set of concentrations gives the association rate $\left(k_{o n}\right)$ up to the point where the system is at equilibrium (i.e., as many association events are observed as dissociation events). Ceasing flow and changing to buffer alone then allows the analyte to wash off the ligand. Measuring the decrease in bound partner over time gives the dissociation rate $\left(k_{o f f}\right)$. The equilibrium dissociation constant $\left(K_{d}\right)$ is calculated from the kinetic association and dissociation rates $\left(k_{o f f} / k_{o n}\right)$. When both association and dissociation rates are too fast, it is possible to use the equilibrium part of the curves to extract the dissociation constant, without relying on the rates. For the SPR experiments, we chose to immobilize the tails on the biosensor surface by using the importins- $\alpha$ as the analytes. The immobilization of the tails was done by fusing a biotinylation sequence in $C_{\text {terminal }}$ (Figure 2a), with a capture strategy based on a biotin: avidin interaction. The corresponding constructs were recombinantly produced in bacteria (with $12.5 \mu \mathrm{g} \cdot \mathrm{mL}^{-1}$ biotin in the growth media) and purified. We first tested their ability to interact with importin- $\alpha 7$ by SEC experiments. They all formed a stable complex in solution with importin- $\alpha 7$ (Figure S1). However, for SPR measurements, the kinetic parameters could not all be established because of technical issues. In particular, for $\mathrm{B} / \mathrm{NP}_{\mathrm{TAIL}}$, the inability to stabilize the SPR signal because of a putative mass transfer phenomenon made it impossible to exploit the raw data. In consequence, we adapted our strategy.

\subsection{Biochemical and Biophysical Analysis of the Interaction between $N P_{\text {TAILS }}$ Fused to Yellow Fluorescent Protein (YFP) and Importin- $\alpha 7$}

We decided to increase the size of the tails by fusing them to a known protein, unrelated to the influenza virus life cycle. A larger ligand should allow the experiment to be performed with lower ligand densities, resulting in lower mass transport rates. We chose the yellow fluorescent protein because of its small size and compact folding, with an unchanged capture strategy on the biosensor surface. A YFP construct was fused in $\mathrm{N}_{\text {terminal }}$ for $\mathrm{C} / \mathrm{NP}_{\mathrm{TAIL}}$ and $\mathrm{D} / \mathrm{NP}_{\mathrm{TAIL}}$ and in $\mathrm{C}_{\text {terminal }}$ for $\mathrm{A} / \mathrm{NP}_{\mathrm{TAIL}}$ and $\mathrm{B} / \mathrm{NP}_{\mathrm{TAIL}}$, to respect their position in the wild-type proteins (Figure $2 \mathrm{~b}$ ). The recombinant proteins were produced, purified (Figure S2) and used in SEC experiments to test their ability to interact with importin- $\alpha 7$. We confirmed that adding the YFP has no visible effect on the interaction between the $\mathrm{NP}_{\text {TAILs }}$ and the human import factor in solution. For each tail, a peak corresponding to the complex was observed prior those of each separate samples (Figure 3). On the contrary, when the control YFP was mixed with importin- $\alpha 7$, a double peak corresponding to the sum of each sample injected separately was observed (Figure S3). 
(a)

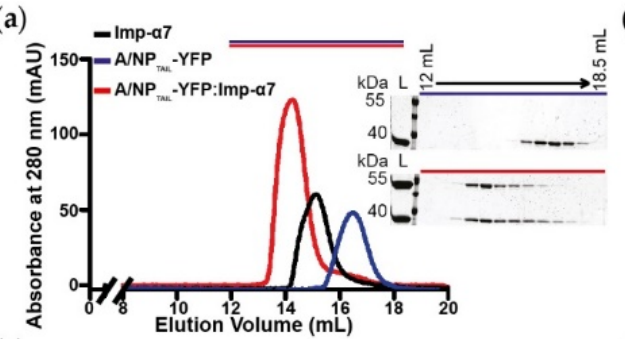

(c)

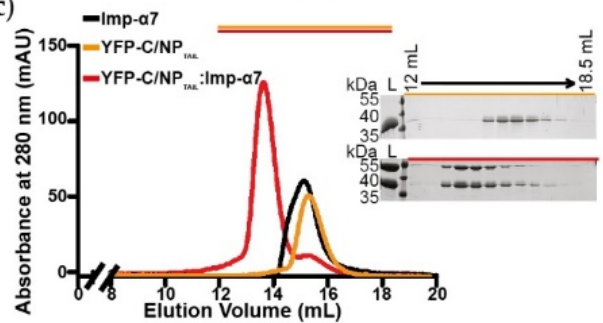

(b)

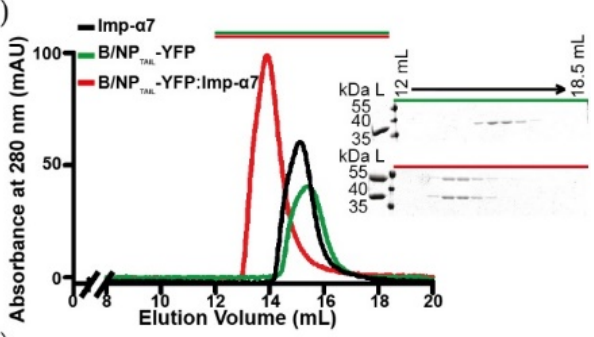

(d)

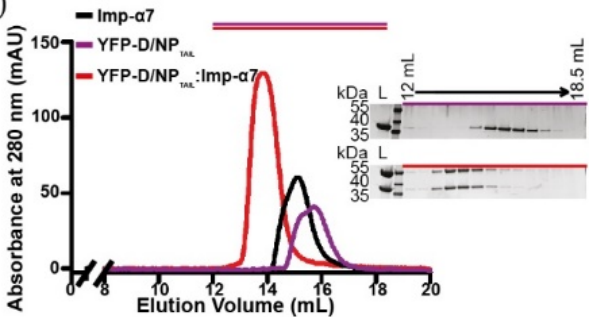

Figure 3. Analysis of the complexes between YFP-NP TAILs and human importin- $\alpha 7$ in solution. Each YFP-NP $_{\text {TAIL }}$ fusion protein $(30 \mu \mathrm{M})$ was injected on a Superdex ${ }^{\mathrm{TM}} 200$ increase 10/300GL column, alone or in the presence of importin- $\alpha 7(25 \mu \mathrm{M})$. The figure shows the superimposition of the SEC profiles obtained for (a) $\mathrm{A} / \mathrm{NP}_{\text {TAIL }}-\mathrm{YFP}$, (b) $\mathrm{B} / \mathrm{NP}_{\mathrm{TAIL}}-\mathrm{YFP}$, (c) YFP-C/NP $\mathrm{NAIL}_{\mathrm{TL}}$ and (d) YFP-D/NP $\mathrm{NAIL}_{\text {TAI }}$. The colors correspond to the code used on Figure $2 \mathrm{~b}$ with all the complexes in red and the importin- $\alpha 7$ alone in black. For each panel, the $12 \%$ SDS-PAGE corresponding to the elution of the YFP-NP TAIL $_{\text {fusion }}$ protein alone (top) and its complex with importin- $\alpha 7$ (bottom) are shown. The control experiment is shown on Figure S3.

Using the corresponding samples, we measured the kinetic parameters of the different interactions by SPR (Figure 4; Tables 2 and 3 respectively for affinities $\left(K_{d}\right)$ and kinetic parameters values $\left(k_{o n}\right.$ and $\left.k_{o f f}\right)$ ). Gradient concentration of importin- $\alpha 7$ were injected into the SPR flowing channels at a speed of $30 / \mu \mathrm{L} \cdot \mathrm{min}^{-1}$ for $50-180 / \mathrm{s}$ to reach equilibrium. As shown in Figure 4 , a binding signal was generated immediately after injection of importin- $\alpha 7$ which dissociated from the sensor chip very quickly, suggesting that importin- $\alpha 7$ bound to the immobilized $\mathrm{NP}_{\text {TAILs }}$ in a quick "in and out" manner. Equilibrium analysis was then chosen to derive affinity binding constants $\left(K_{d}\right)$ for the interaction between the immobilized NP $\mathrm{NAIIs}_{\text {and }}$ and the importin- $\alpha 7$ in solution. Our reference was the data obtained for the interaction between $\mathrm{D} / \mathrm{NP}_{\mathrm{TAIL}}$ and importin- $\alpha 7$ previously measured using the same method and the same strategy [37] but with a previous generation instrument. Using a Biacore 3000, we had measured a $K_{d}$ of $99 \mathrm{nM} \pm 9 \mathrm{nM}$ for this interaction and $29 \mathrm{nM} \pm 1 \mathrm{nM}$ using a new generation Biacore T200. This time, we were able to fully exploit the SPR data obtained with all $\mathrm{NP}_{\text {TAILs. }}$ In particular, we showed that the architecture of the NLS (mono- or bipartite NLS) has no importance for importin- $\alpha 7$; the affinity for the non-conventional monopartite $\mathrm{A} / \mathrm{NP}_{\mathrm{TAIL}}$ was better than for the bipartite $\mathrm{C} / \mathrm{NP}_{\mathrm{TAIL}}$, with $K_{d}$ of $73 \pm 4 \mathrm{nM}$ and $146 \pm 8 \mathrm{nM}$ respectively, but weaker than $\mathrm{D} / \mathrm{NP}_{\mathrm{TAIL}} \cdot \mathrm{B} / \mathrm{NP}_{\mathrm{TAIL}}$ appeared to be the lowest value with a $K_{d}$ of $405 \pm 5 \mathrm{nM}$, but comparable to the value obtained using isothermal titration calorimetry [38]. Despite the nanomolar affinities, all of these interactions displayed a highly dynamic behaviour. Indeed, kinetics parameters show extremely high on rates, suggesting that very little energy is needed to form the interaction, but also very high off rates. Both association and dissociation rates were close to the upper detection limits of the apparatus, respectively around $10^{-6} \mathrm{M}^{-1} \cdot \mathrm{s}^{-1}$ and $0.1 \mathrm{~s}^{-1}$ and even above in the case of the $\mathrm{B} / \mathrm{NP}_{\mathrm{TAIL}}$ (Table 3). 
(a)

(c)

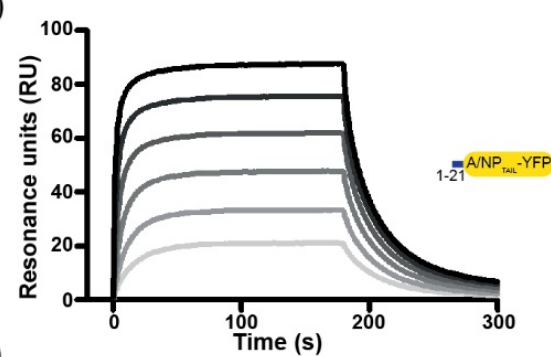

(e)


(b)

(d)

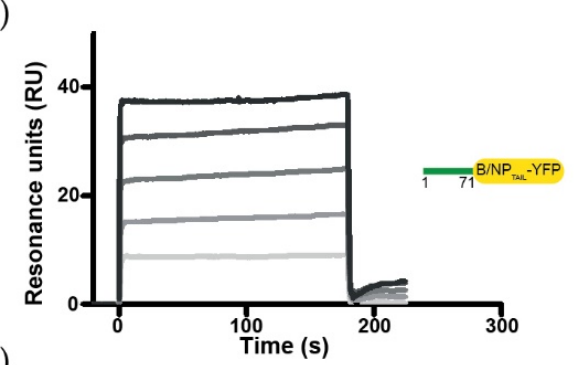

$(\mathbf{f})$
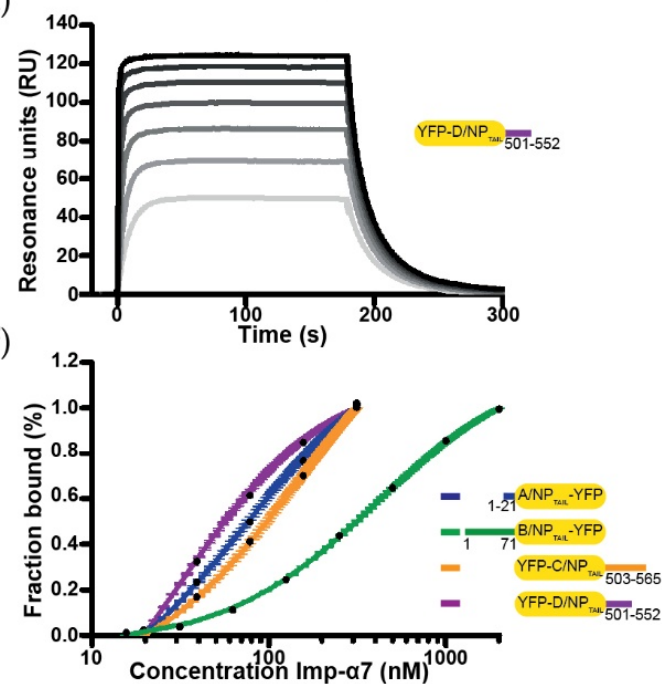


The figure shows the sensorgrams of the interaction between importin- $\alpha 7$ and (a) $\mathrm{A} / \mathrm{NP}_{\mathrm{TAIL}}-\mathrm{YFP}$, (b) $\mathrm{B} / \mathrm{NP}_{\mathrm{TAIL}}-\mathrm{YFP}$, (c) YFP-C/NP $\mathrm{NAIL}_{\mathrm{T}}$ (d) YFP-D/NP $\mathrm{NAII}_{\text {Th }}$ and (e) the YFP control. For each panel, the gradation of grey represents the different concentrations of importin- $\alpha 7$ used for each titration, from the lowest (light-grey) to the highest (dark-grey). The concentrations range from $19.5 \mathrm{nM}$ to $625 \mathrm{nM}$ for (a) and (c), from $125 \mathrm{nM}$ to $2 \mu \mathrm{M}$ for (b), from $19.5 \mathrm{nM}$ to $1.25 \mu \mathrm{M}$ for (d) and from $80.5 \mathrm{nM}$ to $10.3 \mu \mathrm{M}$ for (e). (f) Steady state analysis was performed on Biacore evaluation software, the resulting fitting normalized and plotted on a $\log _{10}$ scale.

Table 2. Affinity between wild-type influenza nucleoprotein tails and human importins- $\alpha$ obtained by SPR. The apparent dissociation constants $\left(K_{d}\right)$ are expressed in nM; n.i. means 'no interaction'.

\begin{tabular}{cccc}
\hline & Imp- $\boldsymbol{\alpha} \mathbf{3}$ & Imp- $\boldsymbol{\alpha} \mathbf{5}$ & Imp- $\boldsymbol{\alpha} \mathbf{7}$ \\
\hline $\mathrm{A} / \mathrm{NP}_{\mathrm{TAIL}}$ & $301 \pm 21$ & $128 \pm 20$ & $73 \pm 4$ \\
$\mathrm{~B} / \mathrm{NP}_{\text {TAIL }}$ & $308 \pm 106$ & $770 \pm 24$ & $405 \pm 5$ \\
$\mathrm{C} / \mathrm{NP}_{\text {TAIL }}$ & $59 \pm 9$ & $287 \pm 31$ & $146 \pm 8$ \\
D/NP & $21 \pm 5$ & $29 \pm 1$ \\
YFP control & $22 \pm 15$ & n.i. & n.i. \\
\hline
\end{tabular}

Table 3. Kinetic parameters of the interaction between wild-type influenza nucleoprotein tails and human importins- $\alpha$ obtained by SPR. The association rate constants $\left(k_{o n}\right)$ are expressed in $\mathrm{M}^{-1} \cdot \mathrm{s}^{-1}$ and the dissociation rate constants $\left(k_{\text {off }}\right)$ values are expressed in $\mathrm{s}^{-1}$; n.i. means 'no interaction'.

\begin{tabular}{ccccccc}
\hline & \multicolumn{2}{c}{ Imp- $\alpha 3$} & \multicolumn{2}{c}{ Imp- $\mathbf{3} 5$} & \multicolumn{2}{c}{ Imp- $\alpha 7$} \\
\hline & $k_{\text {on }}\left(\times 10^{6}\right)$ & $k_{\text {off }}\left(\times 10^{-1}\right)$ & $k_{\text {on }}\left(\times 10^{6}\right)$ & $k_{\text {off }}\left(\times 10^{-1}\right)$ & $k_{\text {on }}\left(\times 10^{6}\right)$ & $k_{\text {off }}\left(\times 10^{-1}\right)$ \\
$\mathrm{A} / \mathrm{NP}_{\text {TAIL }}$ & $1.31 \pm 0.03$ & $2.81 \pm 0.04$ & $1.0 \pm 0.6$ & $1.6 \pm 0.1$ & $1.6 \pm 0.1$ & $0.7 \pm 0.1$ \\
$\mathrm{~B} / \mathrm{NP}_{\text {TAIL }}$ & $>10$ & $>10$ & $>10$ & $>10$ & $>10$ & $>10$ \\
$\mathrm{C}^{\mathrm{N} P_{\text {TAIL }}}$ & $2.4 \pm 1.1$ & $1.3 \pm 0.4$ & $6.1 \pm 3.6$ & $2.6 \pm 0.4$ & $2.6 \pm 0.4$ & $2.5 \pm 0.1$ \\
$\mathrm{D} / \mathrm{NP}_{\text {TAIL }}$ & $2.8 \pm 0.2$ & $0.07 \pm 0.01$ & $1.1 \pm 0.1$ & $5.0 \pm 0.2$ & $5.0 \pm 0.2$ & $1.04 \pm 0.03$ \\
YFP control & n.i. & n.i. & n.i. & n.i. & n.i. & n.i. \\
\hline
\end{tabular}




\subsection{Systematic Analysis of the Interactions between $N P_{\text {TAILs }}$ and Importins- $\alpha$}

Once the strategy for measuring the kinetics of all $\mathrm{NP}_{\mathrm{TAILs}}$ for the importin- $\alpha 7$ was established, we decided to expand it to other members of the importins- $\alpha$ family. The human genome encodes seven isoforms of importin- $\alpha$, divided into three subfamilies known as $\alpha 1, \alpha 2$ and $\alpha 3$ : the $\alpha 1$ subfamily contains importin- $\alpha 1$ and $-\alpha 8$; the $\alpha 2$ subfamily contains importin- $\alpha 3$ and $-\alpha 4$; and the $\alpha 3$ subfamily contains importin- $\alpha 5,-\alpha 6$ and $-\alpha 7[18,49]$. We chose to work with one representative isoform of each subfamily (importin- $\alpha 1$ and importin- $\alpha 3$, respectively for the $\alpha 1$ and $\alpha 2$ subfamilies) plus a second isoform for the $\alpha 3$ subfamily (i.e., importin- $\alpha 5$ ). Furthermore, all these isoforms are described in the literature regarding the influenza virus infection. We produced and purified the recombinant isoforms without their importin- $\beta$ binding (IBB) domain. The case of importin- $\alpha 1$ is shown below. Using SEC-MALLS-RI experiments, we first confirmed that both $\triangle$ IBB importins- $\alpha 3$ and $-\alpha 5$ are monomeric in solution (Figure S4), before we used them in our SPR experiments to determine their respective kinetics (Tables 2 and 3). Importin- $\alpha 5$ shows a similar interaction profile as importin- $\alpha 7$, with $K_{d} \mathrm{D} / \mathrm{NP}_{\text {TAIL }}$ $<\mathrm{A} / \mathrm{NP}_{\text {TAIL }}<\mathrm{C} / \mathrm{NP}_{\text {TAIL }}<\mathrm{B} / \mathrm{NP}_{\text {TAIL }}$ but with a higher amplitude in the values (from 21 to $770 \mathrm{nM}$ ). On the contrary, the architecture of the NLS seems essential for recognition by importin- $\alpha 3$. The two bipartite NLS tails (i.e., $\mathrm{C} / \mathrm{NP}_{\mathrm{TAIL}}$ and $\mathrm{D} / \mathrm{NP}_{\mathrm{TAIL}}$ ) have a higher affinity than the two monopartite (i.e., $\mathrm{A} / \mathrm{NP}_{\mathrm{TAIL}}$ and $\mathrm{B} / \mathrm{NP}_{\mathrm{TAIL}}$ ) which both show identical values. Based on these results, we further deciphered the interactions by introducing point mutations in the positive charge patches of the NLSs which we had analyzed in the past (i.e., $\mathrm{B} / \mathrm{NP}_{\mathrm{TAIL}}$ and $\mathrm{D} / \mathrm{NP}_{\text {TAIL }}$ ) $[37,38]$. We show that for bipartite NLS, the second basic patch could be stronger in relation to the stability of the cargo: importin- $\alpha$ than the first patch (Table 4). Based on the affinities of each single patch mutants, $\mathrm{D} / \mathrm{NP}_{\text {TAIL }}$ seems to present a cooperative behaviour in importin- $\alpha$ binding. On the other hand, importin- $\alpha 7$ seems to be more prompt in compensating for mutations in the first patch whereas importin- $\alpha 3$ looks more permissive to mutations in the second. The results obtained with $\mathrm{B} / \mathrm{NP}_{\mathrm{TAIL}}$ mutant confirm our nuclear magnetic resonance (NMR) observations on the major contribution of the whole tail, from residues 30 to 71 , in the interaction with importins- $\alpha$, and not only the regions surrounding the KR motif [38]. Regarding the $\mathrm{B} / \mathrm{NP}_{\text {TAIL mut } 1}-\mathrm{YFP}$, even if we were not able to quantify precisely the equilibrium dissociation constants from the raw data, probably because importin- $\alpha$ require a longer injection period to saturate all the ligand binding sites in this condition, the sensorgrams show clear concentration dependent-responses in contrast to the YFP-D/NP $\mathrm{NAIL}_{\text {mut3 }}$ construct (Figure S5).

Table 4. Effects of mutations in $\mathrm{B} / \mathrm{NP}_{\mathrm{TAIL}}$ and $\mathrm{D} / \mathrm{NP}_{\mathrm{TAIL}}$ on the affinities for the human importins- $\alpha$. The $K_{d}$ obtained by SPR are expressed in nM; n.i. means 'no interaction'.

\begin{tabular}{|c|c|c|c|}
\hline & $\operatorname{Imp}-\alpha 3$ & $\operatorname{Imp}-\alpha 5$ & $\operatorname{Imp}-\alpha 7$ \\
\hline $\mathrm{B} / \mathrm{NP}_{\mathrm{TAIL}}$ & $308 \pm 106$ & $770 \pm 24$ & $405 \pm 5$ \\
\hline $\mathrm{B} / \mathrm{NP}_{\mathrm{TAIL}}$ mut 1 & $>5000$ & $>5000$ & $>5000$ \\
\hline $\mathrm{D} / \mathrm{NP}_{\mathrm{TAIL}}$ & $22 \pm 15$ & $21 \pm 5$ & $29 \pm 1$ \\
\hline $\mathrm{D} / \mathrm{NP}_{\text {TAIL mut1 }}$ & $922 \pm 77$ & $1150 \pm 154$ & $658 \pm 208$ \\
\hline $\mathrm{D} / \mathrm{NP}_{\text {TAIL mut2 }}$ & $2457 \pm 184$ & $>5000$ & $>5000$ \\
\hline $\mathrm{D} / \mathrm{NP}_{\text {TAIL mut } 3}$ & n.i. & n.i. & n.i. \\
\hline $\mathrm{B} / \mathrm{NP}_{\mathrm{TALL}}$ & 71 & & \\
\hline $\mathrm{B} / \mathrm{NP}_{\text {TAn . mutr }} 1$ & 71 & & \\
\hline 501 & 一 & & \\
\hline $\mathrm{D} / \mathrm{NP}_{\mathrm{TALI} \text { max }}$ & 一 & & \\
\hline $\mathrm{D} / \mathrm{NP}_{\mathrm{TAN} \text {. max }}$ & —AAAGA — & & \\
\hline $\mathrm{D} / \mathrm{NP}_{\mathrm{TAAl} \text { mal3 }}$ & —AAAGA — & & \\
\hline
\end{tabular}

\subsection{The Case of the Importin- $\alpha 1$}

The SEC-MALLS-RI experiments showed a different behaviour of importin- $\alpha 1$ in solution (Figure S4). Whereas the experimental molecular mass for $\triangle$ IBB importins- $\alpha 3,-\alpha 5$ and _ $\alpha 7$ were similar to the theoretical values, the results obtained with $\triangle I B B$ importin- $\alpha 1$ suggest a propensity 
for dimerization of this construct. The corresponding sample was eluted precociously from the S200 column with an apparent molecular mass of $88 \mathrm{kDa}$ rather than the theoretical $50 \mathrm{kDa}$ (Figure S4a). Dimerization was reported previously [50] with a monomer-dimer $K_{d}$ estimated to be $8 \mu \mathrm{M}$ and the equilibrium could be shifted to the monomeric form by adding NLS-mimicking peptides. In a second SEC-MALLS-RI set of experiments but using a Superdex 75 column, we showed that with the different $\mathrm{NP}_{\text {TAIL }}$ peptides the peaks corresponding to the importin- $\alpha 1$ were shifted to the smaller molecular mass (Figure 5a). The largest effect is observed with $\mathrm{D} / \mathrm{NP}_{\text {TAIL }}$ suggesting that a quasi-quantitative estimation of the interaction could be extracted from these results, with apparent $K_{d} \mathrm{D} / \mathrm{NP}_{\mathrm{TAIL}}<$ $\mathrm{C} / \mathrm{NP}_{\mathrm{TAIL}} \leq \mathrm{A} / \mathrm{NP}_{\mathrm{TAIL}}<\mathrm{B} / \mathrm{NP}_{\mathrm{TAIL}}$.

(a)

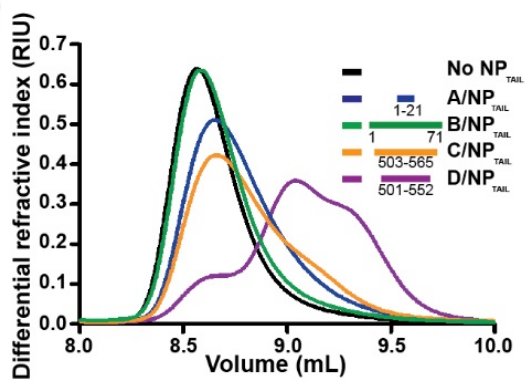

(b)

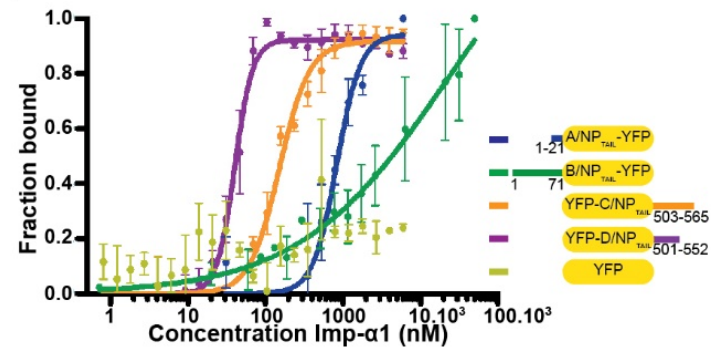

Figure 5. Binding of influenza nucleoproteins tails to importin- $\alpha 1$. (a) Dissociation of importin- $\alpha 1$ dimers by competition with $\mathrm{NP}_{\text {TAIL }}$ using a SEC-MALLS-RI experiments. Human importin- $\alpha 1$ $(45 \mu \mathrm{M})$ alone or incubated with each $\mathrm{NP}_{\mathrm{TAIL}}(45 \mu \mathrm{M})$ was injected on a Superdex ${ }^{\mathrm{TM}} 75$ increase $10 / 300 \mathrm{G}$. Successful competition resulted in a delayed elution volume compared to the importin- $\alpha 1$ alone. Three distinct species can be identified from importin- $\alpha 1: \mathrm{D} / \mathrm{NP}_{\mathrm{TAIL}}$ injection and two species

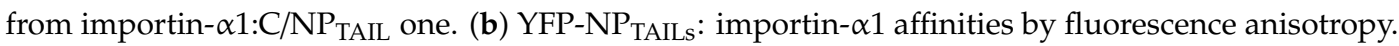
Titration with each $\mathrm{NP}_{\text {TAIL }}(25 \mathrm{nM})$ was carried out by fluorescence anisotropy with importin- $\alpha 1$ concentrations ranging from $0.7 \mathrm{nM}$ to $50 \mu \mathrm{M}$ for $\mathrm{B} / \mathrm{NP}_{\mathrm{TAIL}}-\mathrm{YFP}$ or from $0.8 \mathrm{nM}$ to $6 \mu \mathrm{M}$ for the other constructs. The titrations were normalized and fitted with GraphPad analysis model "specific binding with Hill slope". The raw data are shown in Figure S6.

When we tried to measure the corresponding kinetics by SPR, we could not obtain a stable equilibrium, probably due to the competition between the monomer-dimer transition of importin- $\alpha 1$ and its interaction with the immobilized tails. This experimental artifact is inherent to the nature of the analyte, which despite the purification steps may dimerize in time and significantly affect affinity measurements by SPR. We then found an alternative method; with the YFP-NP ${ }_{\text {TAILs }}$ we could measure the fluorescence anisotropy. Fluorescence anisotropy is a measure of light emitted by a fluorophore, unequal along different axes of polarization. This measure depends on rotational behaviour of this fluorescent molecule in solution. Depending on the fluorophore environment, fluorescence anisotropy will vary from a low value because of its high rotational rate when the molecule is free, to a high value in case of its interaction with a partner. This feature allows the determination of an apparent binding constant when the fluorescent molecule is kept at a constant concentration upon titration of its partner.

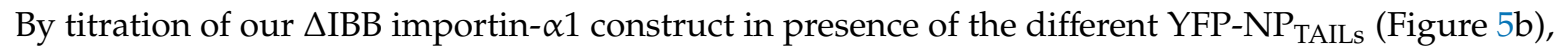
the corresponding apparent $K_{d}$ was determined (Table 5). The curve of the $\mathrm{B} / \mathrm{NP}_{\text {TAIL }}$ could not be estimated because the $K_{d}$ of the $\mathrm{B} / \mathrm{NP}_{\mathrm{TAIL}}$ for importin- $\alpha 1$ was too close to the $K_{d}$ of the dimerization of importin- $\alpha 1$. 
Table 5. Affinity between wild-type influenza nucleoprotein tails and human importin- $\alpha 1$ obtained by fluorescence anisotropy. The apparent $K_{d}$ are expressed in nM; n.d. and n.i. mean 'not determined' and 'no interaction', respectively.

\begin{tabular}{cccccc}
\hline & $\mathbf{A} / \mathbf{N P}_{\text {TAIL }}$ & B/NP $_{\text {TAIL }}$ & $\mathbf{C}_{\mathbf{N} \mathbf{N P}_{\text {TAIL }}}$ & D/NP $_{\text {TAIL }}$ & YFP Control \\
\hline imp $-\alpha \mathrm{l}$ & $621 \pm 89$ & n.d. & $149 \pm 1$ & $41 \pm 12$ & n.i. \\
\hline
\end{tabular}

\section{Discussion}

The interaction between viral proteins and cellular factors is of growing interest for understanding the evolution mechanisms of viruses, and RNA viruses in particular. These are major potential therapeutic targets, as these interfaces are less prone to mutations. It has been decades since the interactions between importin- $\alpha$ and the influenza virus nucleoprotein have been studied but numerous features and mechanisms are still unknown [32,33,35,51]. Importins- $\alpha$ are essential actors in cells and were diversified and highly conserved through evolution (Table S2). Each importin- $\alpha$ shows a high sequence identity in higher eukaryotes with a specific expression pattern and behaviour but also preferential bindings to cargo and functions.

In this paper, we provide a comparative characterization of the interactions between four importin- $\alpha$ isoforms with the tails from $\mathrm{A} / \mathrm{NP}, \mathrm{B} / \mathrm{NP}, \mathrm{C} / \mathrm{NP}$ and $\mathrm{D} / \mathrm{NP}$. The affinities are between the nanomolar and the low micromolar range, with association and dissociation rates surprisingly high. Two different behaviours were identified: (i) $\mathrm{A} / \mathrm{NP}_{\mathrm{TAIL}}, \mathrm{C} / \mathrm{NP}_{\mathrm{TAIL}}$ and $\mathrm{D} / \mathrm{NP}_{\mathrm{TAIL}}$ present a dynamic complex formation and release with high-affinity preferential binding and (ii) $\mathrm{B} / \mathrm{NP}_{\mathrm{TAIL}}$ shows even faster association and dissociation rates with very low affinity.

The $\mathrm{A} / \mathrm{NP}_{\mathrm{TAIL}}$ was isolated from a human strain of influenza $\mathrm{A}$ virus and interacted preferentially with importin- $\alpha 7$. This is consistent with the importins- $\alpha$ expression pattern in the human respiratory track [52] as well as of previously reported work [31]. It is of note that PB2 isolated from human strains also preferentially bind to importin- $\alpha$, while avian PB2s tend to interact with importin- $\alpha 3$ [28]. The poor binding of $\mathrm{A} / \mathrm{NP}_{\text {TAIL }}$ to importin- $\alpha 3$ is consistent with the fact that importin- $\alpha 3$ tends not to interact well with monopartite NLS; while $\mathrm{A} / \mathrm{NP}_{\mathrm{TAIL}}$ is not a monopartite NLS per se, it possesses only a short NLS motif. In contrast, $\mathrm{C} / \mathrm{NP}_{\mathrm{TAIL}}$ presents a higher affinity for importin- $\alpha 3$. Importin- $\alpha 3$ has a low auto-inhibition and a unique intrinsic flexibility, acting as an adapter for unusual and complex NLS sequences or NLS close to globular domains [53,54]. Such NLSs could not associate with a less flexible importin- $\alpha$ due to steric hindrance. The NLS sequence of $C / N P_{\text {TAIL }}$ is similar to a bipartite NLS, with two basic patches, but separated by a long linker sequence (more than 20 residues). Such a sequence could require the flexibility of importin- $\alpha 3$ to achieve optimal binding. $\mathrm{D} / \mathrm{NP}$ TAIL is a textbook case of bipartite NLS, which binds tightly to importins- $\alpha$, using both the minor and major binding pockets [55-57]. $\mathrm{D} / \mathrm{NP}_{\text {TAIL }}$ strongly interacts with all tested importins with a high affinity $(20-41 \mathrm{nM})$, in the same range as other bipartite NLSs $\left(K_{d} \approx 10 \mathrm{nM}\right)[28,58]$. In other studies, it has been shown that the in vitro affinities using purified proteins and peptides were in the nanomolar range whereas the interaction between NLSs and importins- $\alpha$ in cellulo is in the micromolar range. Addition of cytosol in in vitro assays led to the destabilization of importin: NLS complexes, even in the case of bacterial lysate, highlighting the contribution of non-specific interaction and competition in this cellular process $[44,59]$. Importins cycles between both compartments have been estimated to be fast, around $30 \mathrm{~ms}$; nanomolar affinity leads to a residence time of several seconds or up to several minutes, which is far too long to allow optimal release in the nucleus, while micromolar affinity put it in the millisecond range [59].

The sensorgram shapes of $\mathrm{C} / \mathrm{NP}_{\mathrm{TAIL}}$ and $\mathrm{D} / \mathrm{NP}_{\mathrm{TAIL}}$ along with the affinities resulting from $\mathrm{D} / \mathrm{NP}_{\mathrm{TAIL}}$ mutations clearly suggest that the interaction follows a 1:1 binding model with cooperativity. At the other end of the spectrum, $\mathrm{B} / \mathrm{NP}_{\mathrm{TAIL}}$ behaviour towards importins- $\alpha$ is still puzzling. It is possible that the $\mathrm{B} / \mathrm{NP}_{\mathrm{TAIL}}$ is not properly processed in our settings. It is well known that $\mathrm{A} / \mathrm{NP}$ and B/NP nuclear import are regulated through post-translational modifications (PTM), in particular 
through phosphorylation [60,61]. A discrete PTM could be an activating signal for nuclear import regulation [62-66]. The absence of the $\mathrm{NP}_{\mathrm{CORE}}$ in our experiment could also be responsible for the lack of functionality of $\mathrm{B} / \mathrm{NP}_{\mathrm{TAIL}}$ : three-dimensional context could matter for importin specificity, with putative additional contacts and constrains, and for NLS docking $[18,28,53,67]$. Another hypothesis comes from the nuclear import receptor involved and the complex to be imported. While importin- $\alpha / \beta$ complex is largely believed to be the most common nuclear import pathway, this is still debated. Other adaptor proteins besides importin- $\alpha$ are known to interact with cargo and importin- $\beta$ [68,69]. Co-import of neo-synthesized B/NP with another cargo is also a possibility, taking in account that RNP nuclear import functionality putatively relies on avidity rather than affinity $[70,71]$. Therefore, it is not be excluded that B/NP uses another receptor/complex to gain access to the nucleus. Further investigations into other nuclear import receptors could shed light on successful B/NP nuclear translocation. One interesting feature of $\mathrm{B} / \mathrm{NP}$ is its long, intrinsically disordered $\mathrm{N}_{\text {terminal }}$ tail. Such a tail could be involved in the formation of liquid phase separation and help with protein recruitment [72,73]. If B/NP exhibits such behaviour, it could be interesting to dissect it further as nucleoporins in the nuclear pore complex channel tend themselves to be involved in phase separation [74-76].

Our work focuses on human importins- $\alpha$, as three out of the four $\mathrm{NP}_{\text {TAILS }}$ were derived from human viruses. However, due to the high conservation of these importins through evolution (Table S2), it is likely that extrapolation to other mammal importins can be achieved to some degree. Further work would be required to validate this completely.

While a lot of work is still required to fully understand the mechanistic and specificity of the interactions between influenza nucleoproteins and importins- $\alpha$, we provide here this first comparative study on the interaction of $\mathrm{NP}_{\text {TAILs }}$ with importins- $\alpha 1,-\alpha 3,-\alpha 5$ and $-\alpha 7$. NP $\mathrm{CORE}$ involvement, $\mathrm{NP}$ oligomerization, cellular environment, IBB domain contribution, and post-translational modification of both partners are other factors which need to be investigated in the future, in the hope of fully dissecting this host-pathogen interaction and trying to target and disrupt this essential hijacking mechanism.

\section{Conclusions}

While the interactions between influenza NPs and importins- $\alpha$ have been extensively studied, this has mainly been done through the prism of $\mathrm{A} / \mathrm{NP}$, with a large number of highly different methods and sometimes without the essential focus required on importins- $\alpha$. Whereas each method and study brought useful characterization insights, it is a complex task to compare affinity from widely different assays, with significant changes in conditions, partners, settings and analysis. Here, we provide the first comparative study to dissect several interactions between influenza NPs and importins- $\alpha$ using the same strategy and under the same conditions. We showed that $\mathrm{A} / \mathrm{NP}_{\mathrm{TAIL}}, \mathrm{C} / \mathrm{NP}_{\mathrm{TAIL}}$ and $\mathrm{D} / \mathrm{NP} \mathrm{TAIL}_{\mathrm{T}}$ interact strongly with one or several importins- $\alpha$. On the contrary, the human specific $\mathrm{B} / \mathrm{NP}_{\mathrm{TAIL}}$ interacts poorly with selected importins- $\alpha$, raising new questions about this essential interaction in the influenza virus cycle.

Supplementary Materials: The following are available online at http://www.mdpi.com/1999-4915/12/8/834/ s1, Figure S1: analysis of the complexes between $\mathrm{NP}_{\text {TAILS }}$ and human importin- $\alpha 7$ in solution, Figure S2: SEC-MALLS-RI analysis of the different YFP-fused tails used in that work, Figure S3: absence of interaction between YFP and human importin- $\alpha 7$ in solution, Figure S4: SEC-MALLS-RI analysis of the different importins- $\alpha$

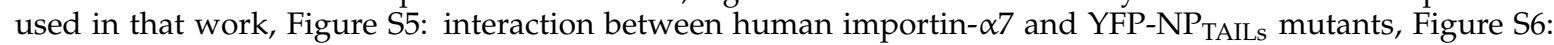

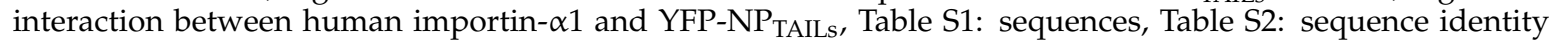
between the importins- $\alpha$ used in the studies.

Author Contributions: T.C. conceived and designed the experiments; A.D., E.V.-S. and F.C.A.G. performed the experiments; A.D., E.V.-S., F.C.A.G. and T.C. analysed the data; A.D. and T.C. wrote the original draft; A.D., E.V.-S., F.C.A.G., R.W.H.R. and T.C. edited the final manuscript. All authors have read and agreed to the published version of the manuscript.

Funding: This work was supported by the Agence Nationale pour la Recherche, grant number ANR-14-CE09-0017.

Acknowledgments: We thank Justine Sensini and Louis Saliceti for their contribution in the samples preparation. We are highly grateful to Jean-Marie Bourhis, Pascal Fender, Corinne Mercier, Carlo Petosa and Antoine Royant for discussions. We thank Darren J Hart for the plasmid to express the human importin- $\alpha 7$. This work used the 
platforms of the Grenoble Instruct-ERIC center (ISBG; UMS 3518 CNRS-CEA-UGA-EMBL) within the Grenoble Partnership for Structural Biology (PSB), supported by FRISBI (ANR-10-INBS-05-02) and GRAL, financed by the University Grenoble Alpes - Ecoles Universitaires de Recherche CBH-EUR-GS (ANR-17-EURE-0003).

Conflicts of Interest: The authors declare no conflict of interest.

\section{References}

1. Shi, M.; Lin, X.D.; Chen, X.; Tian, J.H.; Chen, L.J.; Li, K.; Wang, W.; Eden, J.S.; Shen, J.J.; Liu, L.; et al. The evolutionary history of vertebrate RNA viruses. Nature 2018, 556, 197-202. [CrossRef] [PubMed]

2. Klumpp, K.; Ruigrok, R.W.; Baudin, F. Roles of the Influenza virus polymerase and nucleoprotein in forming a functional RNP structure. EMBO J. 1997, 16, 1248-1257. [CrossRef] [PubMed]

3. Coloma, R.; Arranz, R.; de la Rosa-Trevin, J.M.; Sorzano, C.O.S.; Munier, S.; Carlero, D.; Naffakh, N.; Ortin, J.; Martin-Benito, J. Structural insights into Influenza A virus ribonucleoproteins reveal a processive helical track as transcription mechanism. Nat. Microbiol. 2020, 5, 727-734. [CrossRef] [PubMed]

4. Feldherr, C.M.; Kallenbach, E.; Schultz, N. Movement of a karyophilic protein through the nuclear pores of oocytes. J. Cell Biol. 1984, 99, 2216-2222. [CrossRef] [PubMed]

5. Davis, L.I. The nuclear pore complex. Annu. Rev. Biochem. 1995, 64, 865-896. [CrossRef]

6. Mans, B.J.; Anantharaman, V.; Aravind, L.; Koonin, E.V. Comparative genomics, evolution and origins of the nuclear envelope and nuclear pore complex. Cell Cycle 2004, 3, 1612-1637. [CrossRef]

7. Lin, D.H.; Hoelz, A. The structure of the nuclear pore complex (an update). Annu. Rev. Biochem. 2019, 88, 725-783. [CrossRef]

8. Bonner, W.M. Protein migration into nuclei. II. Frog oocyte nuclei accumulate a class of microinjected oocyte nuclear proteins and exclude a class of microinjected oocyte cytoplasmic proteins. J. Cell Biol. 1975, 64, 431-437. [CrossRef]

9. Chook, Y.M.; Suel, K.E. Nuclear import by karyopherin-betas: Recognition and inhibition. Biochim. Biophys. Acta 2011, 1813, 1593-1606. [CrossRef]

10. Timney, B.L.; Raveh, B.; Mironska, R.; Trivedi, J.M.; Kim, S.J.; Russel, D.; Wente, S.R.; Sali, A.; Rout, M.P. Simple rules for passive diffusion through the nuclear pore complex. J. Cell Biol. 2016, 215, 57-76. [CrossRef]

11. Gorlich, D.; Vogel, F.; Mills, A.D.; Hartmann, E.; Laskey, R.A. Distinct functions for the two importin subunits in nuclear protein import. Nature 1995, 377, 246-248. [CrossRef] [PubMed]

12. Chook, Y.M.; Blobel, G. Karyopherins and nuclear import. Curr. Opin. Struct. Biol. 2001, 11, $703-715$. [CrossRef]

13. Lange, A.; Mills, R.E.; Lange, C.J.; Stewart, M.; Devine, S.E.; Corbett, A.H. Classical nuclear localization signals: Definition, function, and interaction with importin alpha. J. Biol. Chem. 2007, 282, 5101-5105. [CrossRef] [PubMed]

14. Lee, B.J.; Cansizoglu, A.E.; Suel, K.E.; Louis, T.H.; Zhang, Z.; Chook, Y.M. Rules for nuclear localization sequence recognition by karyopherin beta 2. Cell 2006, 126, 543-558. [CrossRef] [PubMed]

15. Bono, F.; Cook, A.G.; Grunwald, M.; Ebert, J.; Conti, E. Nuclear import mechanism of the EJC component Mago-Y14 revealed by structural studies of importin 13. Mol. Cell 2010, 37, 211-222. [CrossRef]

16. Padavannil, A.; Sarkar, P.; Kim, S.J.; Cagatay, T.; Jiou, J.; Brautigam, C.A.; Tomchick, D.R.; Sali, A.; D’Arcy, S.; Chook, Y.M. Importin-9 wraps around the H2A-H2B core to act as nuclear importer and histone chaperone. eLife 2019, 8. [CrossRef] [PubMed]

17. Swale, C.; Da Costa, B.; Sedano, L.; Garzoni, F.; McCarthy, A.A.; Berger, I.; Bieniossek, C.; Ruigrok, R.W.H.; Delmas, B.; Crepin, T. X-ray structure of the human karyopherin RanBP5, an essential factor for Influenza polymerase nuclear trafficking. J. Mol. Biol. 2020, 432, 3353-3359. [CrossRef]

18. Pumroy, R.A.; Cingolani, G. Diversification of importin-alpha isoforms in cellular trafficking and disease states. Biochem. J. 2015, 466, 13-28. [CrossRef]

19. Oka, M.; Yoneda, Y. Importin alpha: Functions as a nuclear transport factor and beyond. Proc. Jpn. Acad. Ser. B Phys. Biol. Sci. 2018, 94, 259-274. [CrossRef]

20. Martin, K.; Helenius, A. Transport of incoming Influenza virus nucleocapsids into the nucleus. J. Virol. 1991, 65, 232-244. [CrossRef]

21. Neumann, G.; Castrucci, M.R.; Kawaoka, Y. Nuclear import and export of Influenza virus nucleoprotein. J. Virol. 1997, 71, 9690-9700. [CrossRef] [PubMed] 
22. Deng, T.; Engelhardt, O.G.; Thomas, B.; Akoulitchev, A.V.; Brownlee, G.G.; Fodor, E. Role of ran binding protein 5 in nuclear import and assembly of the Influenza virus RNA polymerase complex. J. Virol. 2006, 80, 11911-11919. [CrossRef] [PubMed]

23. Hutchinson, E.C.; Orr, O.E.; Man Liu, S.; Engelhardt, O.G.; Fodor, E. Characterization of the interaction between the Influenza A virus polymerase subunit PB1 and the host nuclear import factor Ran-binding protein 5. J. Gen. Virol. 2011, 92, 1859-1869. [CrossRef] [PubMed]

24. Swale, C.; Monod, A.; Tengo, L.; Labaronne, A.; Garzoni, F.; Bourhis, J.M.; Cusack, S.; Schoehn, G.; Berger, I.; Ruigrok, R.W.; et al. Structural characterization of recombinant IAV polymerase reveals a stable complex between viral PA-PB1 heterodimer and host RanBP5. Sci. Rep. 2016, 6, 24727. [CrossRef] [PubMed]

25. Tarendeau, F.; Boudet, J.; Guilligay, D.; Mas, P.; Bougault, C.; Boulo, S.; Baudin, F.; Ruigrok, R.W.H.; Daigle, N.; Ellenberg, J.; et al. Structure and nuclear import function of the C-terminal domain of Influenza virus polymerase PB2 subunit. Nat. Struct. Mol. Biol. 2007, 14, 229-233. [CrossRef] [PubMed]

26. Boivin, S.; Hart, D.J. Interaction of the Influenza A virus polymerase PB2 C-terminal region with importin alpha isoforms provides insights into host adaptation and polymerase assembly. J. Biol. Chem. 2011, 286, 10439-10448. [CrossRef] [PubMed]

27. Hudjetz, B.; Gabriel, G. Human-like PB2 627K Influenza virus polymerase activity is regulated by importin-alpha1 and -alpha7. PLoS Pathog. 2012, 8, e1002488. [CrossRef]

28. Pumroy, R.A.; Ke, S.; Hart, D.J.; Zachariae, U.; Cingolani, G. Molecular determinants for nuclear import of Influenza A PB2 by importin alpha isoforms 3 and 7. Structure 2015, 23, 374-384. [CrossRef]

29. Cros, J.F.; García-Sastre, A.; Palese, P. An unconventional NLS is critical for the nuclear import of the Influenza A virus nucleoprotein and ribonucleoprotein. Traffic 2005, 6, 205-213. [CrossRef]

30. Weber, F.; Kochs, G.; Gruber, S.; Haller, O. A classical bipartite nuclear localization signal on Thogoto and Influenza A virus nucleoproteins. Virology 1998, 250, 9-18. [CrossRef]

31. Wu, W.; Sankhala, R.S.; Florio, T.J.; Zhou, L.; Nguyen, N.L.T.; Lokareddy, R.K.; Cingolani, G.; Pante, N. Synergy of two low-affinity NLSs determines the high avidity of Influenza A virus nucleoprotein NP for human importin alpha isoforms. Sci. Rep. 2017, 7, 11381. [CrossRef] [PubMed]

32. O'Neill, R.E.; Palese, P. NPI-1, the human homolog of SRP-1, interacts with Influenza virus nucleoprotein. Virology 1995, 206, 116-125. [CrossRef]

33. Wang, P.; Palese, P.; O'Neill, R.E. The NPI-1/NPI-3 (karyopherin alpha) binding site on the Influenza a virus nucleoprotein NP is a nonconventional nuclear localization signal. J. Virol. 1997, 71, 1850-1856. [CrossRef] [PubMed]

34. Melen, K.; Fagerlund, R.; Franke, J.; Kohler, M.; Kinnunen, L.; Julkunen, I. Importin alpha nuclear localization signal binding sites for STAT1, STAT2, and Influenza A virus nucleoprotein. J. Biol. Chem. 2003, 278, 28193-28200. [CrossRef] [PubMed]

35. Gabriel, G.; Klingel, K.; Otte, A.; Thiele, S.; Hudjetz, B.; Arman-Kalcek, G.; Sauter, M.; Shmidt, T.; Rother, F.; Baumgarte, S.; et al. Differential use of importin-alpha isoforms governs cell tropism and host adaptation of Influenza virus. Nat. Commun. 2011, 2, 156. [CrossRef]

36. Sasaki, Y.; Hagiwara, K.; Kakisaka, M.; Yamada, K.; Murakami, T.; Aida, Y. Importin alpha3/Qip1 is involved in multiplication of mutant Influenza virus with alanine mutation at amino acid 9 independently of nuclear transport function. PLoS ONE 2013, 8, e55765. [CrossRef]

37. Donchet, A.; Oliva, J.; Labaronne, A.; Tengo, L.; Miloudi, M.; Gerard, F.C.A.; Mas, C.; Schoehn, G.; Ruigrok, R.W.H.; Ducatez, M.; et al. The structure of the nucleoprotein of Influenza D shows that all Orthomyxoviridae nucleoproteins have a similar $\mathrm{NP}_{\mathrm{CORE}}$, with or without a $\mathrm{NP}_{\mathrm{TAIL}}$ for nuclear transport. Sci. Rep. 2019, 9, 600. [CrossRef]

38. Labaronne, A.; Milles, S.; Donchet, A.; Jensen, M.R.; Blackledge, M.; Bourhis, J.M.; Ruigrok, R.W.H.; Crepin, T. Structural analysis of the complex between Influenza B nucleoprotein and human importin-alpha. Sci. Rep. 2017, 7, 17164. [CrossRef]

39. Ozawa, M.; Fujii, K.; Muramoto, Y.; Yamada, S.; Yamayoshi, S.; Takada, A.; Goto, H.; Horimoto, T.; Kawaoka, Y. Contributions of two nuclear localization signals of Influenza A virus nucleoprotein to viral replication. J. Virol. 2007, 81, 30-41. [CrossRef]

40. Ng, A.K.; Zhang, H.; Tan, K.; Li, Z.; Liu, J.H.; Chan, P.K.; Li, S.M.; Chan, W.Y.; Au, S.W.; Joachimiak, A.; et al. Structure of the Influenza virus A H5N1 nucleoprotein: Implications for RNA binding, oligomerization, and vaccine design. FASEB J. 2008, 22, 3638-3647. [CrossRef] 
41. Boulo, S.; Akarsu, H.; Lotteau, V.; Muller, C.W.; Ruigrok, R.W.; Baudin, F. Human importin alpha and RNA do not compete for binding to Influenza A virus nucleoprotein. Virology 2011, 409, 84-90. [CrossRef] [PubMed]

42. Nakada, R.; Hirano, H.; Matsuura, Y. Structure of importin-alpha bound to a non-classical nuclear localization signal of the Influenza A virus nucleoprotein. Sci. Rep. 2015, 5, 15055. [CrossRef] [PubMed]

43. Tang, Y.S.; Lo, C.Y.; Mok, C.K.; Chan, P.K.; Shaw, P.C. The extended C-terminal region of Influenza C virus nucleoprotein is important for nuclear import and ribonucleoprotein activity. J. Virol. 2019, 93, e02048-18. [CrossRef] [PubMed]

44. Timney, B.L.; Tetenbaum-Novatt, J.; Agate, D.S.; Williams, R.; Zhang, W.; Chait, B.T.; Rout, M.P. Simple kinetic relationships and nonspecific competition govern nuclear import rates in vivo. J. Cell Biol. 2006, 175, 579-593. [CrossRef] [PubMed]

45. Mackmull, M.T.; Klaus, B.; Heinze, I.; Chokkalingam, M.; Beyer, A.; Russell, R.B.; Ori, A.; Beck, M. Landscape of nuclear transport receptor cargo specificity. Mol. Syst. Biol. 2017, 13, 962. [CrossRef]

46. Sumarheni, S.; Hong, S.S.; Josserand, V.; Coll, J.L.; Boulanger, P.; Schoehn, G.; Fender, P. Human full-length coagulation factor $X$ and a GLA domain-derived 40-mer polypeptide bind to different regions of the adenovirus serotype 5 hexon capsomer. Hum. Gene Ther. 2014, 25, 339-349. [CrossRef]

47. Wyatt, P.J. Submicrometer particle sizing by multiangle light scattering following fractionation. J. Colloid Interface Sci. 1998, 197, 9-20. [CrossRef]

48. Labaronne, A.; Swale, C.; Monod, A.; Schoehn, G.; Crepin, T.; Ruigrok, R.W. Binding of RNA by the nucleoproteins of Influenza viruses A and B. Viruses 2016, 8, 247. [CrossRef]

49. Mason, D.A.; Stage, D.E.; Goldfarb, D.S. Evolution of the metazoan-specific importin alpha gene family. J. Mol. Evol. 2009, 68, 351-365. [CrossRef]

50. Miyatake, H.; Sanjoh, A.; Unzai, S.; Matsuda, G.; Tatsumi, Y.; Miyamoto, Y.; Dohmae, N.; Aida, Y. Crystal structure of human importin-alpha1 (Rch1), revealing a potential autoinhibition mode involving homodimerization. PLoS ONE 2015, 10, e0115995. [CrossRef]

51. Resa-Infante, P.; Paterson, D.; Bonet, J.; Otte, A.; Oliva, B.; Fodor, E.; Gabriel, G. Targeting importin-alpha7 as a therapeutic approach against pandemic Influenza viruses. J. Virol. 2015, 89, 9010-9020. [CrossRef] [PubMed]

52. Ninpan, K.; Suptawiwat, O.; Boonarkart, C.; Phuangphung, P.; Sathirareuangchai, S.; Uiprasertkul, M.; Auewarakul, P. Expression of importin-alpha isoforms in human nasal mucosa: Implication for adaptation of avian Influenza A viruses to human host. Virol. J. 2016, 13, 90. [CrossRef] [PubMed]

53. Sankhala, R.S.; Lokareddy, R.K.; Begum, S.; Pumroy, R.A.; Gillilan, R.E.; Cingolani, G. Three-dimensional context rather than NLS amino acid sequence determines importin alpha subtype specificity for RCC1. Nat. Commun. 2017, 8, 979. [CrossRef] [PubMed]

54. Smith, K.M.; Tsimbalyuk, S.; Edwards, M.R.; Cross, E.M.; Batra, J.; Soares da Costa, T.P.; Aragao, D.; Basler, C.F.; Forwood, J.K. Structural basis for importin alpha 3 specificity of $\mathrm{W}$ proteins in Hendra and Nipah viruses. Nat. Commun. 2018, 9, 3703. [CrossRef] [PubMed]

55. Robbins, J.; Dilworth, S.M.; Laskey, R.A.; Dingwall, C. Two interdependent basic domains in nucleoplasmin nuclear targeting sequence: Identification of a class of bipartite nuclear targeting sequence. Cell 1991, 64, 615-623. [CrossRef]

56. Fontes, M.R.; Teh, T.; Kobe, B. Structural basis of recognition of monopartite and bipartite nuclear localization sequences by mammalian importin-alpha. J. Mol. Biol. 2000, 297, 1183-1194. [CrossRef]

57. Hodel, M.R.; Corbett, A.H.; Hodel, A.E. Dissection of a nuclear localization signal. J. Biol. Chem. 2001, 276, 1317-1325. [CrossRef]

58. Lokareddy, R.K.; Hapsari, R.A.; van Rheenen, M.; Pumroy, R.A.; Bhardwaj, A.; Steen, A.; Veenhoff, L.M.; Cingolani, G. Distinctive properties of the nuclear localization signals of inner nuclear membrane proteins Heh1 and Heh2. Structure 2015, 23, 1305-1316. [CrossRef]

59. Cardarelli, F.; Bizzarri, R.; Serresi, M.; Albertazzi, L.; Beltram, F. Probing nuclear localization signal-importin alpha binding equilibria in living cells. J. Biol. Chem. 2009, 284, 36638-36646. [CrossRef]

60. Hutchinson, E.C.; Denham, E.M.; Thomas, B.; Trudgian, D.C.; Hester, S.S.; Ridlova, G.; York, A.; Turrell, L.; Fodor, E. Mapping the phosphoproteome of Influenza a and B viruses by mass spectrometry. PLoS Pathog. 2012, 8, e1002993. [CrossRef] 
61. Zheng, W.; Li, J.; Wang, S.; Cao, S.; Jiang, J.; Chen, C.; Ding, C.; Qin, C.; Ye, X.; Gao, G.F.; et al. Phosphorylation controls the nuclear-cytoplasmic shuttling of Influenza A virus nucleoprotein. J. Virol. 2015, 89, 5822-5834. [CrossRef] [PubMed]

62. Terry, L.J.; Shows, E.B.; Wente, S.R. Crossing the nuclear envelope: Hierarchical regulation of nucleocytoplasmic transport. Science 2007, 318, 1412-1416. [CrossRef] [PubMed]

63. Bedford, M.T.; Clarke, S.G. Protein arginine methylation in mammals: Who, what, and why. Mol. Cell 2009, 33, 1-13. [CrossRef] [PubMed]

64. Nardozzi, J.; Wenta, N.; Yasuhara, N.; Vinkemeier, U.; Cingolani, G. Molecular basis for the recognition of phosphorylated STAT1 by importin alpha5. J. Mol. Biol. 2010, 402, 83-100. [CrossRef] [PubMed]

65. Wang, Y.E.; Pernet, O.; Lee, B. Regulation of the nucleocytoplasmic trafficking of viral and cellular proteins by ubiquitin and small ubiquitin-related modifiers. Biol. Cell. 2012, 104, 121-138. [CrossRef] [PubMed]

66. Ptak, C.; Wozniak, R.W. SUMO and nucleocytoplasmic transport. Adv. Exp. Med. Biol. 2017, 963, 111-126.

67. Friedrich, B.; Quensel, C.; Sommer, T.; Hartmann, E.; Kohler, M. Nuclear localization signal and protein context both mediate importin alpha specificity of nuclear import substrates. Mol. Cell. Biol. 2006, 26, 8697-8709. [CrossRef]

68. Jullien, D.; Gorlich, D.; Laemmli, U.K.; Adachi, Y. Nuclear import of RPA in Xenopus egg extracts requires a novel protein XRIPalpha but not importin alpha. EMBO J. 1999, 18, 4348-4358. [CrossRef]

69. Narayanan, U.; Ospina, J.K.; Frey, M.R.; Hebert, M.D.; Matera, A.G. SMN, the spinal muscular atrophy protein, forms a pre-import snRNP complex with snurportin1 and importin beta. Hum. Mol. Genet. 2002, 11, 1785-1795. [CrossRef]

70. Hodges, J.L.; Leslie, J.H.; Mosammaparast, N.; Guo, Y.; Shabanowitz, J.; Hunt, D.F.; Pemberton, L.F. Nuclear import of TFIIB is mediated by Kap114p, a karyopherin with multiple cargo-binding domains. Mol. Biol. Cell 2005, 16, 3200-3210. [CrossRef]

71. Tome-Amat, J.; Ramos, I.; Amanor, F.; Fernandez-Sesma, A.; Ashour, J. Influenza A virus utilizes low-affinity, high-avidity interactions with the nuclear import machinery to ensure infection and immune evasion. J. Virol. 2019, 93, e01046-18. [CrossRef] [PubMed]

72. Schuster, B.S.; Reed, E.H.; Parthasarathy, R.; Jahnke, C.N.; Caldwell, R.M.; Bermudez, J.G.; Ramage, H.; Good, M.C.; Hammer, D.A. Controllable protein phase separation and modular recruitment to form responsive membraneless organelles. Nat. Commun. 2018, 9, 2985. [CrossRef] [PubMed]

73. Guseva, S.; Milles, S.; Jensen, M.R.; Salvi, N.; Kleman, J.P.; Maurin, D.; Ruigrok, R.W.H.; Blackledge, M. Measles virus nucleo- and phosphoproteins form liquid-like phase-separated compartments that promote nucleocapsid assembly. Sci. Adv. 2020, 6, eaaz7095. [CrossRef] [PubMed]

74. Milles, S.; Mercadante, D.; Aramburu, I.V.; Jensen, M.R.; Banterle, N.; Koehler, C.; Tyagi, S.; Clarke, J.; Shammas, S.L.; Blackledge, M.; et al. Plasticity of an ultrafast interaction between nucleoporins and nuclear transport receptors. Cell 2015, 163, 734-745. [CrossRef] [PubMed]

75. Zilman, A. Aggregation, phase separation and spatial morphologies of the assemblies of FG nucleoporins. J. Mol. Biol. 2018, 430, 4730-4740. [CrossRef] [PubMed]

76. Dormann, D. FG-nucleoporins caught in the act of liquid-liquid phase separation. J. Cell Biol. 2020, 219, e201910211. [CrossRef]

(C) 2020 by the authors. Licensee MDPI, Basel, Switzerland. This article is an open access article distributed under the terms and conditions of the Creative Commons Attribution (CC BY) license (http://creativecommons.org/licenses/by/4.0/). 